\title{
Wheat and maize relay-planting with straw covering increases water use efficiency up to $46 \%$
}

\author{
Wen Yin • Aizhong Yu • Qiang Chai • Falong Hu • \\ Fuxue Feng • Yantai Gan
}

Accepted: 14 January 2015 / Published online: 4 February 2015

(C) INRA and Springer-Verlag France 2015

\begin{abstract}
Family farms in populated countries must produce sufficient quantities of food to meet the ever-growing population needs. It is unknown whether innovated farming systems can alleviate this issue. Here, we carried out field experiments in arid northwest China from 2009 to 2012 to determine the response of water use, grain yield, and water use efficiency. We integrated crop intensification via relay-planting and straw mulching in the same system. Straw mulching included stubble standing, straw covering, or straw incorporation to the soil. Results show that wheat and maize relay-planting with straw mulching increased yields by up to $153 \%$ versus monoplanting of maize and wheat. Straw covering approached the highest yield. Relay-planting with stubble standing or straw covering decreased water consumption by $4.6 \%$. The integrated systems increased water use efficiency by up to $46 \%$ compared to conventional mono-planting maize and wheat.
\end{abstract}

Keywords Oasis region - Relay-planting - Soil waterstorage · Straw mulch · Water use efficiency

\section{Introduction}

In populated countries, such as China, India, and Indonesia, a large part of the rural population lives on small-scaled, self-

W. Yin $\cdot$ A. Yu $\cdot$ Q. Chai $\cdot$ F. Hu $\cdot$ F. Feng

Gansu Provincial Key Laboratory of Aridland Crop Science,

Lanzhou 730070, China

W. Yin $\cdot$ A. Yu $\cdot$ Q. Chai $(\bowtie) \cdot$ F. Hu

College of Agronomy, Gansu Agricultural University,

Lanzhou 730070, China

e-mail: Chaiq@gsau.edu.cn

Y. Gan $(\bowtie)$

Agriculture and Agri-Food Canada, Semiarid Prairie Agricultural

Research Centre, Swift Current, SK S9H 3X2, Canada

e-mail: gan@agr.gc.ca sufficient family farms. Those farms are responsible for the majority of the food production in their respective countries (FAOSTAT 2014). To meet the goals of continuously producing sufficient quantities of food to satisfy the increasing needs for food and fiber by the ever-growing population while optimizing the use of the limited resources, the small-scale family farms must adopt innovative farming systems that are more productive, profitable, resource efficient, and environmentally friendly (Garnett et al. 2013). However, in many rural communities, the family farms are threatened by deterioration of the natural resource base (Fergusson 2013), the competition of available resources with other sectors or urbanization (Poumanyvong et al. 2012), and the degradation of soil quality due to unsustainable farming practices (Powlson et al. 2011).

An overwarming issue threatening agricultural sustainability in some of the regions is water shortage. For example, in northwestern China, average freshwater availability is about $760 \mathrm{~m}^{3}$ per capita per year, a level that is $25 \%$ below the internationally accepted threshold of water scarcity (Shalizi 2006). Annual precipitation is between 50 and $150 \mathrm{~mm}$, while annual evaporation is between 2100 and $2400 \mathrm{~mm}$. Crop production is nearly impossible without irrigation. In the major grain producing areas such as the Hexi Corridor of Gansu Province, surface water available for agriculture has become severely shortaged (Chai et al. 2014), while the depth of the underground water table has declined significantly due to overexploitation of groundwater for irrigation (Zhang 2007). The quantity of water available for agriculture has been decreasing, and crop productivity is seriously threatened with the current production systems.

Wheat (Triticum aestivum L.) and maize (Zea mays L.) are the two main grain crops grown in arid northwestern China, where the two crops are usually "relay-planted" together in an intensified cropping system (Qin et al. 2013). Cool-season spring wheat is planted in strips soon after spring thaw to capture the early-part of the growing season, and then warmseason maize is planted in alternate strips beside the wheat in the same field to accompany the growing cool-season 
component. After wheat harvest, maize continues their growth until freeze-up. This relay-planting system allows the production of two crops within a single season in areas where one crop after another has not been possible due to the limited frost-free days. This intensive cropping system has been shown to increase crop yields (Li et al. 2001), enhance natural resource use efficiency (Fang et al. 2010), and provide greater economic benefits (Zhang and Li 2003). In some cases, the relay-planting system can double the grain yield of the corresponding mono-planting crops (Qin et al. 2013), and significantly improve land utilization rate (Mu et al. 2013). However, this system has been shown to use a significantly great amount of water during the growing season (Fan et al. 2008). A huge conflict exists between increased grain yield by using relay-planting and reduced water availability for agriculture. An important question is that can we develop an integrated system that can continuously capture the features of the crop intensification for high grain yield, while, at the same time, optimizing or reducing the use of the limited water resources. Therefore, we integrated together the following two key components - (i) crop intensification via relay-planting and (ii) water conservation through three straw mulching approaches in integrated systems. The objectives were to determine (i) the effect of integrated systems on crop yield and land utilization efficiency, (ii) the water consumption characteristics and water use efficiency of the integrated systems, and (iii) the response of water use competition and compensation between relay-planting crops to different straw management practice. Our central hypothesis was that there was a great advantage to increase crop productivity while minimizing crop water use with the integrated approach. The hypothesis was tested using a 3-year field experiment conducted in an oasis region of northwest China.

\section{Materials and methods}

Field experiments were conducted at the Wuwei Experimental Station $\left(37^{\circ} 96^{\prime} \mathrm{N}, 102^{\circ} 64^{\prime} \mathrm{E}\right)$ of Gansu Agricultural University, in 2009-2012. The area, located in the eastern part of the Hexi Corridor of northwestern China, is in a typical temperate arid zone of continent, with average annual sunshine duration higher than $2945 \mathrm{~h}$, annual mean air temperature of $7.2^{\circ} \mathrm{C}$, accumulated air temperature above $10{ }^{\circ} \mathrm{C}$ higher than $2985{ }^{\circ} \mathrm{C}$, and the frost-free period is 155 days. Mean annual precipitation is below $150 \mathrm{~mm}$, and potential evaporation is $2400 \mathrm{~mm}$. The soil at the experimental site is classified as a desert soil, a kind of desert land filled with calcareous particles. During the three study years, the wheat growing season (March-July) precipitation was $58.8 \mathrm{~mm}$ in 2010, $65.8 \mathrm{~mm}$ in 2011, and $40.5 \mathrm{~mm}$ in 2012; the maize growing season (AprilSeptember) precipitation was $94.7 \mathrm{~mm}$ in $2010,179.1 \mathrm{~mm}$ in 2011, and $128.5 \mathrm{~mm}$ in 2012.

\subsection{The design of the integrated systems}

In this study, we integrated two key components together in alternative cropping systems: (i) crop intensification with wheat and maize relay-planting and (ii) water conservation through various straw mulching approaches. The wheat and maize relay-planting and the corresponding wheat and maize mono-plantings were tested in four crop-straw mulching systems, forming a $2 \times 4$ factorial design with three replicates in a total of 24 plots $(2$ cropping systems $\times 4$ straw mulching systems $\times 3$ replicates). Spring wheat ( $c$. Yong-liang 4, a popularly grown cultivar) was planted on 20 March in 2010, 28 March in 2011, and 19 March in 2012; maize (cv. Wu-ke 2, a popular-grown hybrid) was planted on 22 April, 17 April, and 20 April, respectively, in the 3 years. Each plot was $48 \mathrm{~m}^{2}$ $(10 \mathrm{~m} \times 4.8 \mathrm{~m})$ with a $0.5-\mathrm{m}$ wide by $0.3-\mathrm{m}$ high ridge between two neighboring plots to eliminate potential movement of irrigation water. Wheat and maize crops were alternated in sets of $160 \mathrm{~cm}$ wide strips. Each wheat strip (80 cm wide) consisted of 6 rows of wheat spaced at $12 \mathrm{~cm}$ between rows, and the maize strip ( $80 \mathrm{~cm}$ wide) had two rows of maize plants with $40 \mathrm{~cm}$ row spacing. Planting density was $6,750,000$ plants per hectare for wheat and 82,500 plants per hectare for maize. Urea (46-0-0 of $\left.\mathrm{N}-\mathrm{P}_{2} \mathrm{O}_{5}-\mathrm{K}_{2} \mathrm{O}\right)$ and diammonium phosphate (18-46-0 of $\mathrm{N}-\mathrm{P}_{2} \mathrm{O}_{5}-\mathrm{K}_{2} \mathrm{O}$ ) were broadcast and incorporated into the top $30-\mathrm{cm}$ soil layer with a shallow rotary tillage prior to sowing. The $\mathrm{N}$ rates were $225 \mathrm{~kg} \mathrm{~N}^{-1}$ for mono-planting wheat and $360 \mathrm{~kg} \mathrm{~N}^{-1}$ for mono-planting maize; $\mathrm{P}$ rates to the mono-planting wheat and maize were 150 and $225 \mathrm{~kg} \mathrm{P}_{2} \mathrm{O}_{5} \mathrm{ha}^{-1}$, respectively. For relay-planting, each species received the same rate of fertilizers on a per land area basis as the mono-planting crops, i.e., the $\mathrm{N}$ and $\mathrm{P}$ rates were halved for each particular species because wheat and maize in the wheat and maize relay-planting occupied one half of the total land area as compared to the mono-planting crops. All N and $\mathrm{P}$ were applied as base fertilizers for wheat. For maize, $30 \%$ of $\mathrm{N}$ was applied at sowing, $60 \%$ applied at jointing, and the remaining $10 \%$ at the grain-filling stage.

For water conservation treatments, four approaches were examined: (i) no-till with straw standing, i.e., NTSS, where no-till was combined with $25 \mathrm{~cm}$ height of wheat straw standing in the field after wheat conservation the previous fall; (ii) no-till with straw covering, i.e., NTS, where no-till was combined with wheat straw of $25 \mathrm{~cm}$ high that was chopped and evenly spread on the soil surface at wheat conservation the previous fall; (iii) tillage with straw incorporation, i.e., TIS, where $25 \mathrm{~cm}$ high of wheat straw was incorporated into the soil through tillage at wheat conservation the previous fall; and (iv) conventional tillage, i.e., CT, where conventional deep $(30 \mathrm{~cm})$ plowing was applied to the plot with straw removed off the field. These four treatments were applied to both monoplanting and the wheat and maize relay-planting systems (Table 1). Wheat strips were rotated with maize strips in 
alternate years (Table 1); this was designed to provide the crops with an "intra-field strip rotation" to avoid potential weakness or problems that may occur with continuous cultivation. Also, the "intra-field strip rotation" may help balance soil nutrients required by the two different crops in the alternate strips.

Due to low precipitation, irrigation was applied to the crops according to the recommendations for optimizing crop production in the local areas. All plots received an amount of $120 \mathrm{~mm}$ of irrigation the previous winter just before soil freezing, and then various irrigation quotas were applied at the different growth stages the current year to satisfy the treatment requirements. A hydrant pipe system was used for the irrigation, and a flow meter was installed at the discharging end of the pipe to record the irrigation amounts entering each plot.

\subsection{Data collection}

\subsubsection{Grain yield and land equivalent ratio}

At full maturity, all plots were harvested by hand, and the grains were air-dried, cleaned, and weighed for grain yield. Land equivalent ratio (LER) was used to assess the yield

Table 1 The detailed description of treatments in 2010, 2011, and 2012

\begin{tabular}{|c|c|c|}
\hline $\begin{array}{l}\text { Treatment } \\
\text { abbreviation }^{\mathrm{a}}\end{array}$ & $\begin{array}{l}\text { Tillage and straw } \\
\text { management on wheat }\end{array}$ & Inter-strips rotation \\
\hline Mono-planting & & $\begin{array}{l}\text { Year } 1 \text {-year 2-year 3- } \\
\quad \text { year } 4\end{array}$ \\
\hline NTSS & $\begin{array}{l}\text { No-till with } 25-\mathrm{cm} \\
\text { straw standing }\end{array}$ & $\begin{array}{l}\text { Wheat — maize - wheat- } \\
\text { maize }\end{array}$ \\
\hline NTS & $\begin{array}{l}\text { No-till with } 25-\mathrm{cm} \\
\text { straw covering }\end{array}$ & $\begin{array}{l}\text { Wheat — maize — wheat- } \\
\text { maize }\end{array}$ \\
\hline TIS & $\begin{array}{l}\text { Tillage with } 25-\mathrm{cm} \\
\text { straw incorporated }\end{array}$ & $\begin{array}{l}\text { Wheat - maize — wheat- } \\
\text { maize }\end{array}$ \\
\hline $\mathrm{CT}$ & Conventional tillage & $\begin{array}{l}\text { Wheat — maize - wheat- } \\
\text { maize }\end{array}$ \\
\hline \multicolumn{3}{|l|}{ Relay-planting } \\
\hline NTSS & $\begin{array}{l}\text { No-till with } 25-\mathrm{cm} \\
\text { straw standing }\end{array}$ & $\begin{array}{l}\text { Wheat - maize - wheat- } \\
\text { maize } \\
\text { Maize - wheat - maize- } \\
\text { wheat }\end{array}$ \\
\hline NTS & $\begin{array}{l}\text { No-till with } 25-\mathrm{cm} \\
\text { straw covering }\end{array}$ & $\begin{array}{l}\text { Wheat - maize - wheat- } \\
\text { maize } \\
\text { Maize - wheat - maize - whe }\end{array}$ \\
\hline TIS & $\begin{array}{l}\text { Tillage with } 25-\mathrm{cm} \\
\text { straw incorporated }\end{array}$ & $\begin{array}{l}\text { Wheat - maize - wheat- } \\
\text { maize } \\
\text { Maize - wheat - maize - whea }\end{array}$ \\
\hline $\mathrm{CT}$ & Conventional tillage & $\begin{array}{l}\text { Wheat - maize - wheat- } \\
\text { maize } \\
\text { Maize - wheat - maize - whe }\end{array}$ \\
\hline
\end{tabular}

${ }^{\text {a }}$ The experiment in 2009 was to provide various wheat straw management options for the treatments implemented in the following years. Systematic data measurement in 2010-2012 advantage of relay-planting as compared to mono-planting crops. LER is defined as the total land area required by mono-planting crops to produce the same quantity of grain yield obtained in the relay-planting, as follows:

$\mathrm{LER}=\mathrm{LER}_{\mathrm{A}}+\mathrm{LER}_{\mathrm{B}}=\frac{Y_{\mathrm{int} A}}{Y_{\text {monoA }}}+\frac{Y_{\text {int } B}}{Y_{\text {mono } B}}$

where $\mathrm{Y}_{\mathrm{int} A}$ and $\mathrm{Y}_{\mathrm{int} B}$ are the yields of relay-planted crop $\mathrm{A}$ and $\mathrm{B}$, and $\mathrm{Y}_{\text {топо } A}$ and $\mathrm{Y}_{\text {топов }}$ are the yields of corresponding mono-planting crops $\mathrm{A}$ and $\mathrm{B}$. $\mathrm{LER}_{A}$ and $\mathrm{LER}_{B}$ are the land equivalent ratios of the relay-planted crop $\mathrm{A}$ and $\mathrm{B}$. A value of LER higher than 1.0 indicates a yield advantage of relayplanting over the corresponding mono-planting crops, and vice versa (Willey 1979).

\subsubsection{Soil water content}

Soil water content (\%) in each crop was measured at an interval of 20 days during the entire growing season; therefore, it was measured 2 points of wheat and maize strips in the relay-planting system, respectively, where the water content in the 0 to 10,10 to 20 , and 20 to $30 \mathrm{~cm}$ depths were measured using oven-drying method, while a neutron probe (NMM503DR, CA, USA) was used to measure soil water content in the 30 to 50,50 to 80 , and 80 to $110 \mathrm{~cm}$ depths. The probes were installed in wheat and maize strips in the relay-planting plot, and between the two central rows in the mono-planting plots. The average value of the two strips was used for the relay-planting treatments. Soil water content was also measured prior to and after each irrigation.

Soil water content standard curve was established by the numerical was measured by the neutron probe: soil water content was measured in different soil layers by the neutron probe and oven-drying method before sowing, after harvest, before irrigation, and after irrigation, and then using the linear regression equation, get the relationship between the numerical of the neutron probe and soil water content. Fitting curve equation as follows:

$$
\theta \%=\left(0.3308 \times \frac{R}{R_{0}}+0.0319\right) \times 100 \% \quad R^{2}=0.9723
$$

where $\theta$ is the soil water content, $R$ is the actual numerical was measured by neutron probe, and $R_{0}$ is the basic numerical of neutron probe.

\subsubsection{Soil evaporation}

Micro-lysimeters were used to measure soil evaporation from the inter-rows of crops, a method similar to that used by other researchers (Plauborg 1995). All micro-lysimeters were 
constructed using polyvinyl chloride tubes with the length of $150 \mathrm{~mm}$, internal diameter of $110 \mathrm{~mm}$, and external diameter of $115 \mathrm{~mm}$. The base of the tubes was sealed with waterproof tape. Micro-lysimeters were situated in the central rows of wheat, maize, and between wheat and maize strips. Microlysimeter was filled with soil and placed into a larger polyvinyl chloride tube, internal diameter of $120 \mathrm{~mm}$, which was installed in the field position prior. Micro-lysimeters were weighed at about 18:00 each day, and daily evaporation was calculated from the weight loss of the micro-lysimeter. Weight loss was recorded at the plot site using a portable balance that weighed to $\pm 0.2 \mathrm{~g}$, and $1 \mathrm{~g}$ change was equivalent to $0.1053 \mathrm{~mm}$ of soil evaporation. The soil evaporation for a plot was represented by the mean value of three lysimeters' readings.

\subsubsection{Evapotranspiration}

Evapotranspiration (ET) was determined using the equation as follows (Chai et al. 2014):

$\mathrm{ET}=P c+I+U-R-D_{W}-\Delta S$

where $P c$ is the effective precipitation $(\mathrm{mm})$, determined by the USDA soil conservation services method (Kuo et al. 2006), $I$ the irrigation quota $(\mathrm{mm}), U$ the upward capillary flow from the root zone (mm), $R$ the runoff $(\mathrm{mm}), D_{w}$ the downward drainage out the root zone $(\mathrm{mm})$, and $\Delta S$ the change of soil water stored in the $0-120 \mathrm{~cm}$ layer $(\mathrm{mm})$. The upward and downward flows were measured previously at a nearby field, and these two items have been found to be negligible in this semiarid area. Runoff was also negligible due to small rains, and irrigation was controlled by raised ridges between plots.

\subsubsection{Water use efficiency}

Water use efficiency (WUE) was calculated using the following equation:

$\mathrm{WUE}=Y / \mathrm{ET}$

where $Y$ is the grain yield $\left(\mathrm{kg} \mathrm{ha}^{-1}\right)$, and ET is the total evapotranspiration over the whole growing season $(\mathrm{mm})$, calculated from Eq. (3) described above.

\subsection{Statistical analysis}

Data were analyzed using the mixed effect of the SPSS statistical analysis software (SPSS software, 17.0, SPSS Inst. Ltd., USA) with the treatment as the fixed effect and replicate as random effect. Due to significant year by treatment interactions for most of the variables evaluated in the study, the treatment effect was assessed separately for each year. All statistical significances were declared at the probability level of 0.05 .

\section{Results and discussions}

\subsection{Integrated systems boosted crop yields}

Compared to mono-planting maize without straw mulching, i.e., the control treatment, the integrated system of wheat and maize relay-planting coupled with straw mulching increased yield by 23 to $42 \%$ compared to conventional mono-planting maize, and increased by 130 to $153 \%$ compared to conventional mono-planting wheat. In particular, the relay-planting with straw covering on the soil surface, the most productive system, increased maize grain yield by $42 \%$ in 2010 and $38 \%$ in 2012 (Table 2); similarly and more dramatically, the integrated systems increased wheat grain yield by $153 \%$ in 2011 compared to the mono-planting wheat.

Wheat and maize relay-planting produced significantly higher grain yields than the mono-planting crops in each of the 3 years (Table 2). In 2010, wheat and maize relay-planting had an average yield of $15,407 \mathrm{~kg} \mathrm{ha}^{-1}$ which was $21.5 \%$ greater than the mono-planting maize. In 2011, wheat and maize relay-planting had an average yield of $15,566 \mathrm{~kg} \mathrm{ha}^{-1}$ which was $135.5 \%$ greater than the mono-planting wheat, which was grown on maize stubble from the previous year. Similarly, in 2012, wheat and maize relay-planting had an average yield of $15,246 \mathrm{~kg} \mathrm{ha}^{-1}$ which was $21.7 \%$ greater than the mono-planting maize. This level of yield increase with relay-planting translated into an increased "land equivalent ratio" of 1.51 to 1.63 , meaning that the mono-planting wheat would need $63 \%$ additional farmland and the monoplanting maize would need $51 \%$ additional farmland in order to produce the same quantity of grain yield as the wheat and maize relay-planting.

A close examination of the two intercrops in their relative contribution to the total yield revealed that the increased grain yield with the relay-planting systems was attributable more to the relay-planted maize and less to the relay-planted wheat. The maize in the relay-planting occupied only $1 / 2$ of the total land area $(80 \mathrm{~cm}$ of maize strip alternated with $80 \mathrm{~cm}$ of wheat strip in each set of the $160 \mathrm{~cm}$ wide area), but the relay-planted maize produced about $80 \%$ of the grain yield of the monoplanting maize in 2010 and $84 \%$ in 2012 .

For the second component of the integration systems, it was consistent that straw mulching coupled with reduced tillage increased grain yield significantly compared to the control treatment in each of the 3 years (Table 2). Averaged across 
Table 2 Grain yields of wheat and maize in mono-planting and wheat and maize relay-planting systems under different treatments at an oasis region, in 2010-2012

\begin{tabular}{|c|c|c|c|c|c|c|c|c|c|c|c|c|}
\hline \multirow[t]{2}{*}{ Treatment } & \multicolumn{4}{|l|}{2010} & \multicolumn{4}{|l|}{2011} & \multicolumn{4}{|l|}{2012} \\
\hline & Wheat & $\begin{array}{l}\text { Maize } \\
\mathrm{kg} \mathrm{ha}^{-1}\end{array}$ & Total $^{\mathrm{a}}$ & $\begin{array}{l}\mathrm{P}^{\mathrm{b}} \\
\%\end{array}$ & Wheat & $\begin{array}{l}\text { Maize } \\
\mathrm{kg} \mathrm{ha}^{-1}\end{array}$ & Total & $\begin{array}{l}\mathrm{P} \\
\%\end{array}$ & Wheat & $\begin{array}{l}\text { Maize } \\
\mathrm{kg} \mathrm{ha}^{-1}\end{array}$ & Total & $\begin{array}{l}\mathrm{P} \\
\%\end{array}$ \\
\hline \multicolumn{13}{|l|}{ Mono-planting } \\
\hline NTSS & - & 13,054 & 13,054 & 21.5 & 6700 & - & 6700 & 135.5 & - & 13,050 & 13,050 & 21.7 \\
\hline NTS & - & 13,470 & 13,470 & & 6858 & - & 6858 & & - & 13,247 & 13,247 & \\
\hline TIS & - & 12,760 & 12,760 & & 6496 & - & 6496 & & - & 12,157 & 12,157 & \\
\hline $\mathrm{CT}$ & - & 11,460 & 11,460 & & 6383 & - & 6383 & & - & 11,650 & 11,650 & \\
\hline \multicolumn{13}{|l|}{ Relay-planting } \\
\hline NTSS & 5326 & 10,518 & 15,844 & & 5432 & 10,398 & 15,829 & & 4991 & 10,621 & 15,611 & \\
\hline NTS & 5203 & 11,101 & 16,304 & & 5193 & 10,972 & 16,165 & & 4687 & 11,377 & 16,064 & \\
\hline TIS & 5355 & 9865 & 15,220 & & 5199 & 10,369 & 15,568 & & 4772 & 10,173 & 14,946 & \\
\hline $\mathrm{CT}$ & 5155 & 9107 & 14,261 & & 4899 & 9806 & 14,703 & & 4505 & 9857 & 14,362 & \\
\hline$P$ value ${ }^{\mathrm{c}}$ & 0.000 & 0.000 & 0.000 & & 0.000 & 0.001 & 0.000 & & 0.005 & 0.000 & 0.000 & \\
\hline $\operatorname{LSD}(0.05)$ & 307 & 404 & 309 & & 370 & 436 & 133 & & 397 & 325 & 214 & \\
\hline
\end{tabular}

The total yields of wheat and maize relay-planting coupled with straw covering on the soil surface is the highest; increasing effect on yield is very significant compared to conventional mono-planting maize, conventional mono-planting wheat, and wheat and maize relay-planting without straw retention

NTSS no-till with straw standing, NTS no-till with straw covering, TIS tillage with straw incorporation, $C T$ conventional tillage without straw retention

${ }^{\text {a }}$ Total yields are the sum of the yields produced by the two component crop

${ }^{\mathrm{b}} \mathrm{P}$ is the abbreviation on the word "percentage", percentage is the ratio on increasing of the average yields of relay-planting compared to the average yield of mono-planting

${ }^{\mathrm{c}}$ The $p$ value and the LSD (0.05) were for all the treatments in the column

years, no-till with straw standing, with straw covering, and tillage with straw incorporation to the soil increased grain yield by $10.3,12.9$, and $5.8 \%$, respectively, compared to the conventional control treatment when the crops were in the mono-planting systems. Similarly, the three straw mulching systems increased grain yield by $9.2,12.0$, and $5.6 \%$, respectively, compared to the control in the relay-planting systems. Among the three straw mulching treatments, the system with reduced tillage coupled with straw covering on the soil surface achieved the highest grain yield, regardless of the monoplanting or relay-planting systems.

Numerous studies have shown that relay-planting has yield advantages over their corresponding mono-plantings (Gao et al. 1999; Li et al. 2001; Ansari and Rana 2012), but the increased grain yield is typically at the expense of increased water consumption. Little has been reported on how the yield advantage can be captured in areas with annual evaporation more than 20 times precipitation. Some studies show that straw mulching can help increase crop establishment and grain yield (Fan et al. 2013), but little is known about how this technique may be effective in relay-planting systems. In the present study, we integrated together the two key components, relay-planting coupled with straw mulching, in alternative systems, and we quantified the relative contribution of the two components to the crop yield. The contribution to the yield of the three relay-planting with straw mulching is composed of two key components, including the relative contribution of relay-planting and straw mulching. The relative contribution of straw mulching is calculated by mono-planting cropping with straw mulching compared to conventional tillage without straw retention; while the remaining key component of the increased yield was attributable to the relay-planting. Therefore, a close examination of the two key components for each of the three integration systems in 2010 revealed that for the system-A, about $86 \%$ of the increased yield was attributable to the first component of the integration (i.e., relay-planting) and the remaining $14 \%$ of the increased yield was attributable to the second component (i.e., straw standing) under relay-planting in combination with straw standing; for the system-B, about $82 \%$ of the increased yield was attributable to relay-planting and the remaining $18 \%$ of the increased yield was attributable to straw covering on the soil surface under relay-planting in combination with straw covering; for the system-C, about $89 \%$ of the increased yield was attributable to relay-planting and the remaining $11 \%$ was attributable to straw incorporated into the soil under relay-planting in combination with straw incorporation. In 2011 and 2012, the effects of the integrated systems on crop yields were similar to 
those obtained in 2010; these two values were, respectively, 95 and $5 \%$ for the relay-planting in combination with straw standing, 93 and $7 \%$ for the relay-planting in combination with straw covering, and 98 and $2 \%$ for the relay-planting in combination with straw incorporation. In 2012, these values were, respectively, 88 and $12 \%$ for the relay-planting in combination with straw standing, 86 and $14 \%$ for the relay-planting in combination with straw covering, and 96 and $4 \%$ for the relay-planting in combination with straw incorporation.
Among the three mulching approaches, relay-planting and straw covering on the soil surface achieved the highest crop yields. The fact that over $80 \%$ of the increased yield was due to relay-planting and about $20 \%$ due to straw mulching suggests that relayplanting is more important to boosting crop yield in areas with the growing season not long enough for two crops per year, and that there is a great potential to capture those features of relay-planting by improving straw management (Fig. 1).
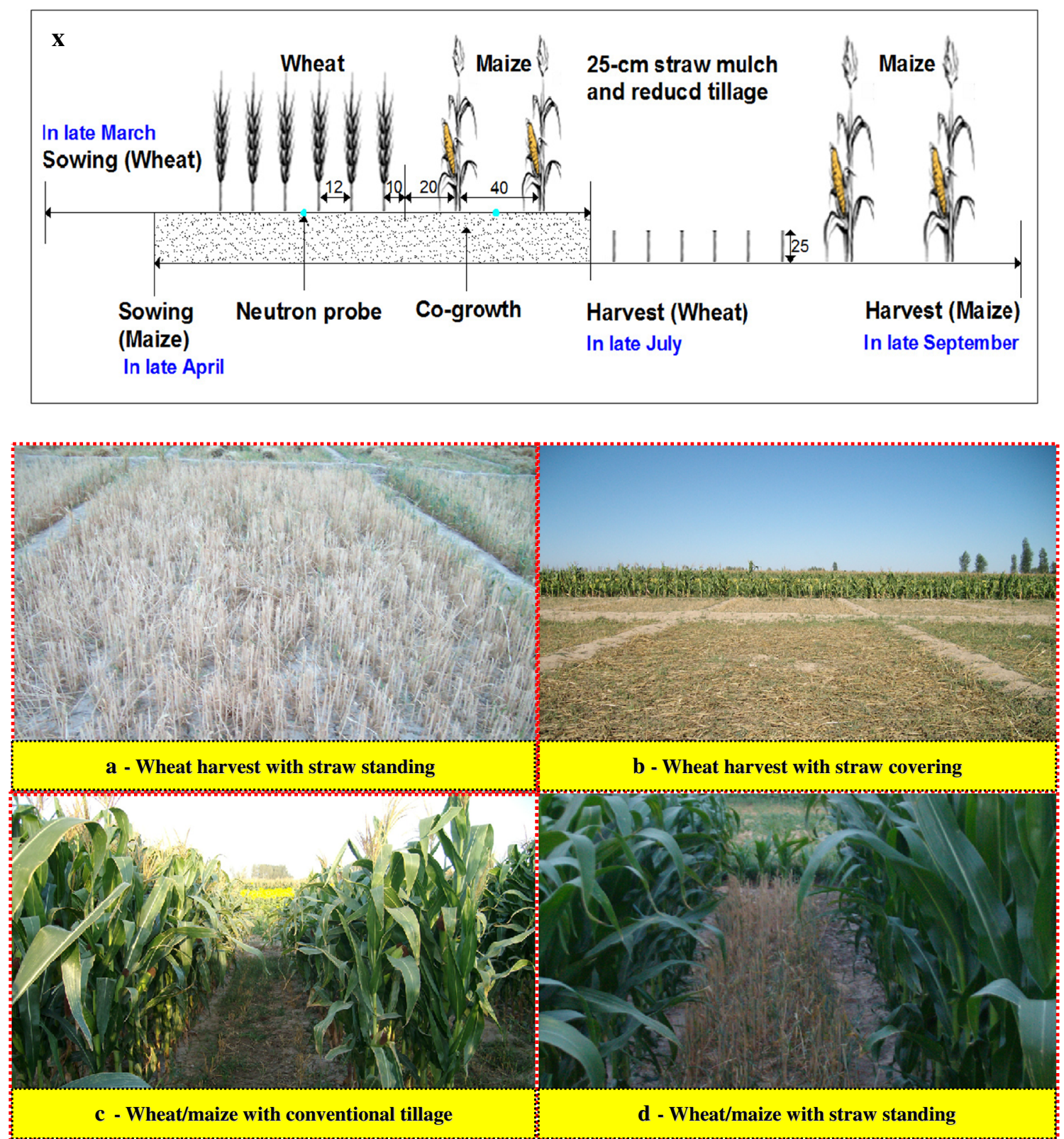

Fig. 1 Field layout of wheat and maize relay-planting with a strip of $80 \mathrm{~cm}$ of wheat (six rows) alternated with a strip of $80 \mathrm{~cm}$ of maize (two rows) between wheat and maize strips $(X)$ Different wheat straw management approaches applied to the mono-planting or relay-planting systems after wheat harvest with a wheat straw standing in the field under mono-planting, b wheat straw was chopped and evenly spread on the soil surface, $\mathbf{c}$ wheat straw was removed out of the field under wheat and maize relay-planting, and $\mathbf{d}$ wheat stubble standing in the wheat strips in the wheat and maize relay-planting system 


\begin{tabular}{|c|c|c|c|c|c|c|c|}
\hline & 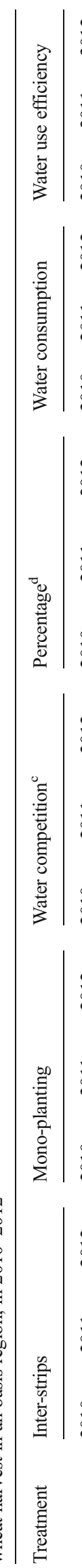 & 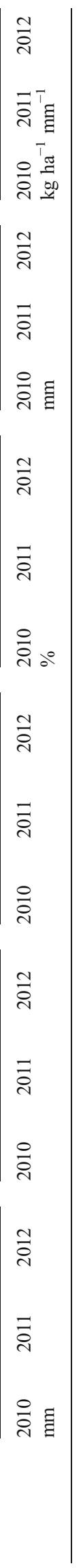 & \multicolumn{3}{|c|}{ 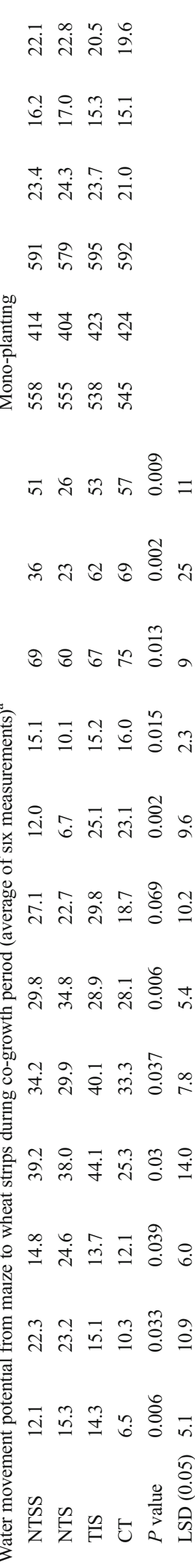 } & 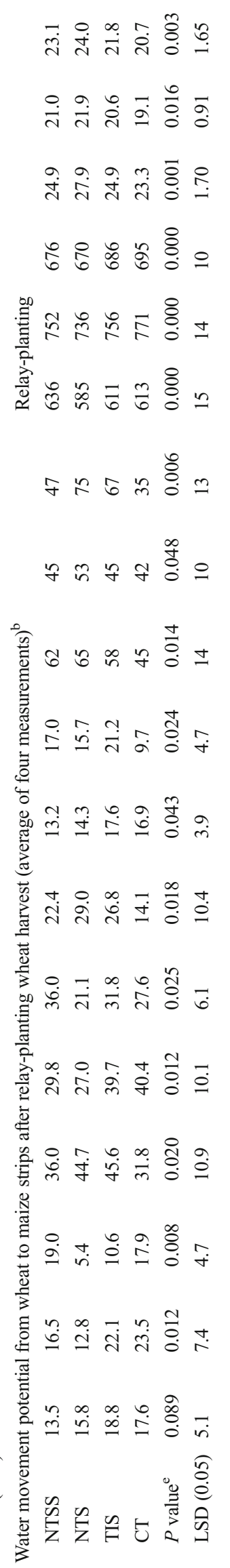 & 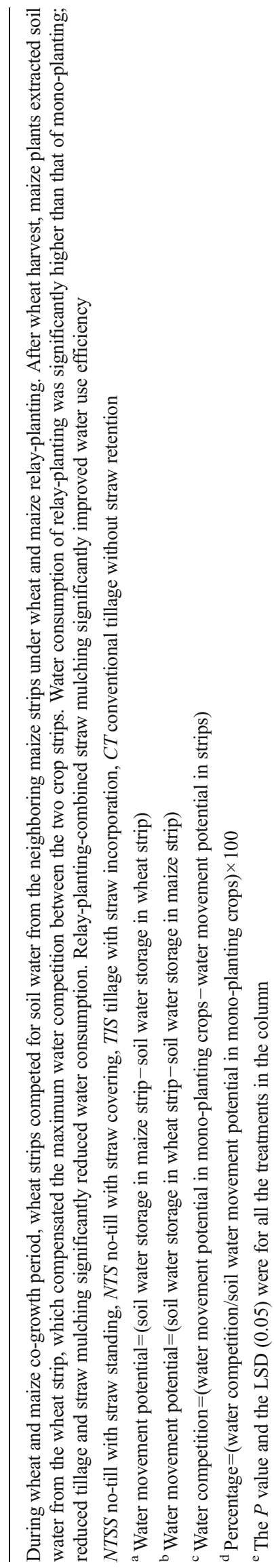 \\
\hline
\end{tabular}




\subsection{Integrated systems improved soil water status}

In each year, detailed measurements of soil water status and crop water use were taken before sowing and during the wheat and maize co-growth period (Table 3 and Fig. 2). In the wheat and maize relay-planting, soil water status were also monitored during the period wheat was growing while maize had not been sown and during the period wheat had been harvested while maize was still growing (Fig. 1x). These monitoring efforts allowed a detailed assessment of soil water changes at the various plant growth stages and the potential water movement between the wheat and maize strips.

\subsubsection{Soil water content across the soil profile}

Across the 0 - to $110-\mathrm{cm}$ soil profile, soil water content increased with the soil depth for all the treatments evaluated in the study (Fig. 2). At a given depth, soil water content in the maize strips was significantly greater than that in the wheat strips, with the largest differences between the two strips being in the 0 - to $30-\mathrm{cm}$ depth. In this soil layer, maize strips had
$5.5 \%$ greater soil water content than the wheat strips in 2010 (Fig. 2x), $5.4 \%$ greater in 2011 (Fig. 2y), and 6.9\% greater in 2012 (Fig. 2z). Below the 50-cm depth, maize strips had similar soil water contents as the wheat strips, with no statistical differences, in any of the study years.

Compared to conventional tillage without straw mulching, straw mulching with reduced tillage increased the wheat strip water content in the 0 to $30 \mathrm{~cm}$ depth by an average of $2.2 \%$ in 2010 (Fig. 2a), $2.0 \%$ in 2011 (Fig. 2b), and $2.4 \%$ in 2012 (Fig. 2c), and it increased maize strip water content by 8.4, 3.0, and $5.0 \%$, respectively, in the 3 years (Fig. $2 \mathrm{~d}-\mathrm{f}$ ). Among the mulching approaches, reduced tillage and straw covering on the soil surface achieved the highest soil water content. From 80 to $110 \mathrm{~cm}$ soil depth, straw mulching with reduced tillage increased soil water content by an average of $4.2 \%$ in wheat strips in 2010, $6.7 \%$ in 2011, and $9.0 \%$ in 2012; the straw mulching also increased the water content in the maize strips by $5.0 \%$ in 2010 and $3.9 \%$ in 2011 . These results indicate that soil water difference is mainly reflected in the topsoil layer, with straw covering on the soil surface having an overwhelmingly positive effect on water status in the soil profile.
Fig. 2 Soil water content in the 0 to $110 \mathrm{~cm}$ depth measured in the wheat and maize strips under different straw mulching approaches. $\mathbf{x}, \mathbf{y}$, and $\mathbf{z}$ represents soil water content of wheat and maize strips by relay-planting in 2010, 2011, and 2012, respectively. $\mathbf{a}, \mathbf{b}$, and $\mathbf{c}$ represents soil water content of wheat strips under different relay-planting treatments, respectively.

Similarly, $\mathbf{d}, \mathbf{e}$, and $\mathbf{f}$ represent soil water content of maize strips. The numbers on the very right are LSD values between the treatments at the given soil depth $(P \leq 0.05)$. NS no significant differences, NTS no-till with straw covering, TIS tillage with straw incorporation, $C T$ conventional tillage without straw retention. Soil water content in maize strips up to $30 \mathrm{~cm}$ depth is higher than that of wheat strips in $\mathbf{x}-\mathbf{z}$, straw mulching with reduced tillage increased soil water content in wheat and maize strips up to $30 \mathrm{~cm}$ depth in $\mathbf{a}-\mathbf{c}$ and $\mathbf{d}-\mathbf{f}$
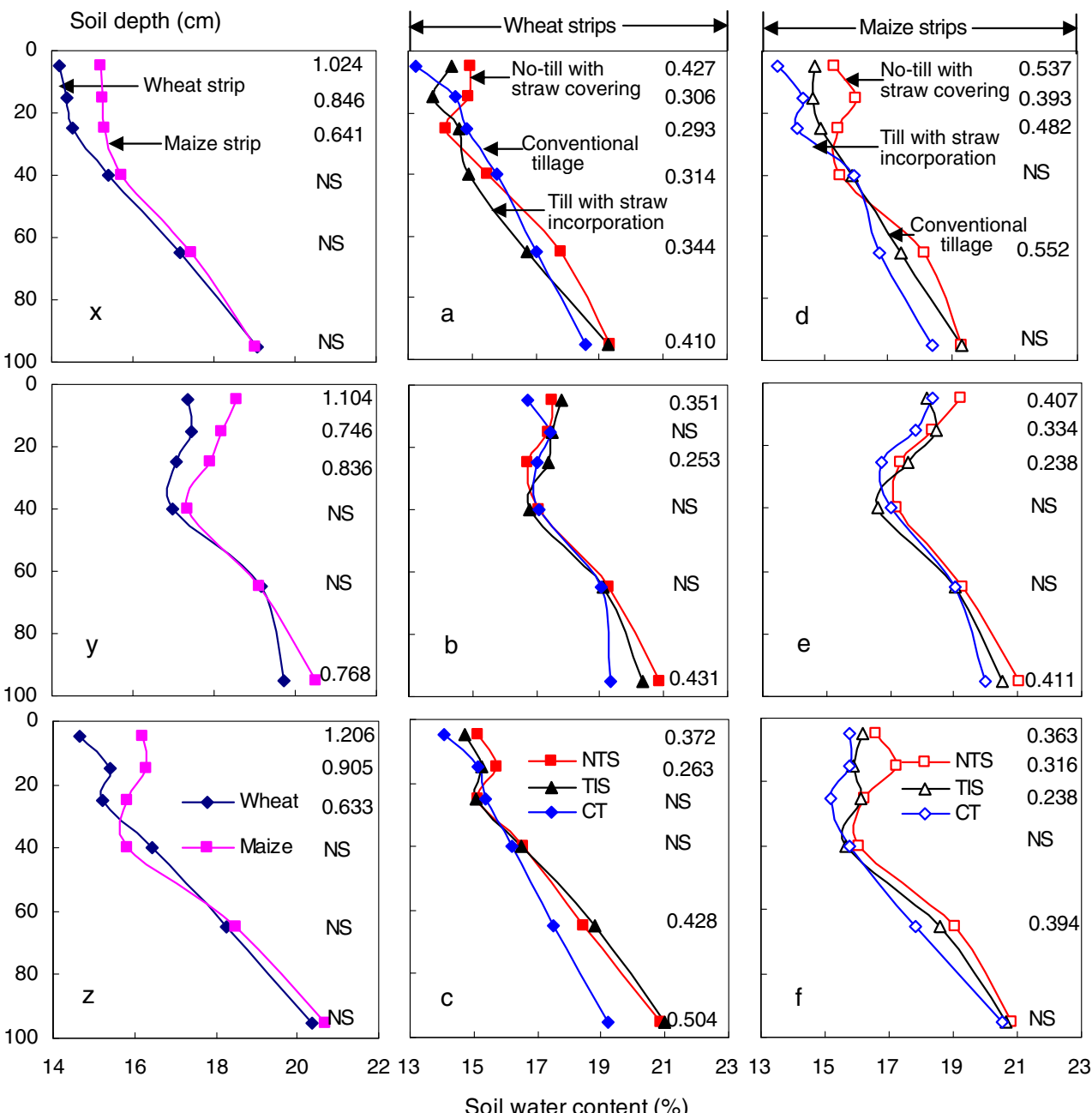


\subsubsection{Soil water movement and competition}

We hypothesized that there was competition for soil water in the root zones between wheat and maize in the alternate strips in the relay-planting system. To quantify this effect, we monitored water status in each strip during the entire growing season, including the co-growth period and the period presowing of maize and post-harvest of wheat crops (Fig. 1x). Soil water movement potential between the two strips was expressed by the differences between high water strip and low water strip in the relay-planting as compared to the corresponding mono-planting plots (Table 3). In 2010, soil water moved from the maize strip to the wheat strip during their cogrowth period by an average of 12.1, 15.3, 14.1, and $6.5 \mathrm{~mm}$ in the no-till with straw standing, with straw covering, tillage with straw incorporation, and the control treatments, respectively; similarly, in 2011, water movements were 22.3, 23.2, 15.1 , and $10.3 \mathrm{~mm}$, respectively; and in 2012 , water movements were 14.8, 24.6, 13.7, and $12.1 \mathrm{~mm}$, respectively.

"Water competition" is a term used to quantify how much water one component crop may compete with the other component crop when they are grown in alternate strips as compared to the corresponding mono-planting crops (Table 3). During the co-growth period in 2010 , wheat strips competed for soil water from the neighboring maize strips at the amounts of 18.7 to $29.8 \mathrm{~mm}$ varying among wheat and maize relayplanting treatments. The amounts of water in competition between the two strips accounted for about 60 to $75 \%$ of the maximum water movement potential from the maize strip to the wheat strip among wheat and maize relay-planting treatments. In 2011 and 2012, the similar trends of water competition effects were observed as those in 2010 . The water competition between wheat strip and the maize strip represented 23 to $69 \%$ of the maximum water movement potential in 2011, and 26 to $57 \%$ in 2012. Among the straw mulching treatments, wheat and maize relay-planting under straw covering on the soil surface gave rise to the highest amount of soil water that was moved to the wheat strip from the maize strip, with the wheat strip having the lowest intendance of competition for soil water. Here, we show that the integrated system of wheat and maize relay-planting coupled with straw covering on the soil surface can significantly reduce soil water losses from the wheat strips and lowering the competition intendance from the neighboring maize strips during their co-growth period.

After wheat harvest (late July to early August), soil water in the wheat strips largely evaporated because no crop was grown, but it was partly used by the maize plants actively growing in the neighboring strips; this was supported by the fact that soil water content in the wheat strips was $58 \%$ lower compared to mono-planting wheat plots in 2011 (16.4 vs. $39.5 \mathrm{~mm}$ : average soil water content of relay-planting vs. mono-planting after wheat harvest), $46 \%$ lower in 2011
(18.7 vs. $34.2 \mathrm{~mm}$ ), and $56 \%$ lower in 2012 (13.2 vs. $29.1 \mathrm{~mm}$ ) (Table 3). This phenomenon of water movement from wheat strips to maize strips after wheat harvest was consistent across all the treatments; this movement compensated water requirement by the growing maize plants. In 2010, soil water compensated to the maize strips from the wheat strips accounted for $62,65,58$, and $45 \%$ of the maximum water competition potential, respectively, for the maize plants in the no-till with straw standing, with straw covering, tillage with straw incorporation, and the control systems. In 2011, the corresponding values were $45,53,45$, and $42 \%$, respectively; and in 2012, the corresponding values were $47,75,67$, and $35 \%$, respectively. Among the straw mulching treatments, wheat and maize relay-planting under straw covering allowed the highest amount of the left, unused water to be moved from the wheat strips to the maize strips, and the control the lowest. Here, we show that no-till with straw covering on the soil surface reduces soil water competition and maintains water balance between wheat strips and maize strips in the relay-planting system. Straw mulch has been shown to prevent soil evaporation in relay-planting systems when the earlier-planted component crop is harvested (Wang et al. 2004). Furthermore, straw mulching has been shown to decrease the depth of crop rooting in some cases, leading to reduced root interaction and competition between the two relay-planted crops during their cogrowth period (Liu et al. 2014).

\subsection{Integrated systems reduced crop water consumption and enhanced crop water use efficiency}

At plant maturity, soil moisture in the wheat and maize relayplanting combined with straw covering on the soil surface was $13.9,20.7$, and $10.4 \%$ greater compared to the control in 2010, 2011, and 2012, respectively (data not presented). The increased soil moisture was largely because straw covering on the soil surface decreased soil evaporation under the limited water condition. In 2010, total water consumption (in $\mathrm{mm}$ ) for the wheat and maize relay-planting combined with straw covering on the soil surface was $4.6 \%$ lower compared to the control. In 2011, total water consumption for the wheat and maize relay-planting combined with straw standing or straw covering on the soil surface was 2.5 and $4.5 \%$ lower; and in 2012, they were 2.7 and $3.6 \%$ lower. Averaged over the 3 years, the wheat and maize relay-planting combined with straw standing or covering reduced soil evaporation by 7.5 and $8.9 \%$ compared to the control. Straw mulching has been proven to be one of the most effective water conservation practices in maintaining soil moisture, reducing water evaporation, and decreasing water consumption (Cantero-Martınez et al. 2003; Blaise et al. 2005). Usually, straw mulching can slow down air convection on the soil surface and thus decreasing the evaporation of soil moisture (Kang and Zhang 2004). 
In some cases, straw mulching forms a barrier against evaporation, helping in maintaining water stored in the rooting zone (Lichter et al. 2008).

An integration of improved farming practices can significantly increase water use efficiency in crop production (Gan et al. 2014). Reduced evaporation from soils and increased soil water available to the crops are among the approaches with which water use efficiency can be improved in the rainfed farming systems (Cooper and Gregory 1987; Huang et al. 2008; Zhang et al. 2007; Gan et al. 2013). In the present study, we found that the wheat and maize relay-planting significantly improved water use efficiency compared to the corresponding mono-planting systems. The integrated system increased water use efficiency by 11 to $33 \%$ compared to the conventional mono-planting maize and increased by 37 to $46 \%$ compared to the conventional mono-planting wheat. In particular, the integrated system of wheat and maize relay-planting combined with straw covering on the soil surface increased water use efficiency by $33 \%$ in 2010 and $22 \%$ in 2012 compared to the mono-planting maize under the control treatment. More dramatically, the integrated system increased water use efficiency by $46 \%$ in 2011 compared to the mono-planting wheat under the control treatment.

A close examination of the two key components of each of the three straw mulching systems revealed that for system-A, about $89 \%$ of the improved water use efficiency in 2010 was attributable to the first component of the integration (i.e., relay-planting) and the remaining $11 \%$ of the improved water use efficiency was attributable to the second component (i.e., straw standing) under relay-planting combined with straw standing; for system$\mathrm{B}$, about $85 \%$ of the improved water use efficiency in 2010 was attributable to relay-planting and the remaining $15 \%$ of the improved water use efficiency was attributable to straw covering on the soil surface under relayplanting combined with straw covering; for system-C, about $87 \%$ of the improved water use efficiency in 2010 was attributable to relay-planting and the remaining $13 \%$ of the improved water use efficiency was attributable to straw incorporated into the soil under relayplanting combined with straw incorporation; in 2011, these two values were, respectively, 92 and $8 \%$ of relayplanting combined with straw standing, 87 and $13 \%$ of relay-planting combined with straw covering, 98 and $2 \%$ of relay-planting combined with straw incorporation; in 2012 , these respective values were 87 and $13 \%$ of relay-planting combined with straw standing, 84 and $16 \%$ of relay-planting combined with straw covering, and 95 and $5 \%$ of relay-planting combined with straw incorporation. Among the three mulching approaches, relay-planting and straw covering on the soil surface achieved the highest relative contribution rate on water use efficiency of the straw mulching systems.

\section{Conclusions}

The integrated systems of wheat and maize relay-planting combined with straw mulching can decrease soil evaporation, reduce water consumption, and increase crop yield and water use efficiency significantly, compared to conventional monoplanting wheat and maize. Wheat and maize relay-planting coupled with straw covering on the soil surface was most significant, which decreased water consumption by 3.6 to $4.6 \%$ compared to conventional relay-planting system during the 3 years; increased grain yield by 38 to $42 \%$ compared to conventional mono-planting maize and by $153 \%$ compared to conventional mono-planting wheat; and increased water use efficiency by 22 to $33 \%$ compared to conventional monoplanting maize and by $46 \%$ compared to conventional mono-planting wheat. During the wheat and maize cogrowth period, wheat strips competed for soil water from the neighboring maize strips under wheat and maize relay-planting. After relay-planting wheat harvest, maize plants extracted soil water from wheat strip, which compensated water competition between wheat and maize strips. The 3 years of field study showed consistent results that the integrated system with crop intensification coupled with straw covering on the soil surface can serve a proven, effective water conservation technique for increasing crop yield, while improving water use efficiency in arid irrigation areas. We acknowledge that this study was conducted for 3 years only. Although the results were consistent between the study years, more site-years of experimentation may be required in order to validate the suitability of this model to different environmental conditions.

Acknowledgments We are grateful to the research grants provided by the National Natural Science Foundation of China (31360323), the Excellent Youth Foundation of Gansu Scientific Committee (1111RJDA006), National Key Technology R\&D Program (2012BAD14B10), and Outstanding Talent Culture Project of Gansu Agricultural University. We would also like to thank all the staff at Wuwei Experimental Station of Gansu Agricultural University for technical assistance in carrying out the field experiments.

\section{References}

Ansari MA, Rana KS (2012) Effect of transpiration suppressants and nutrients on productivity and moisture-use efficiency of pearlmillet (Pennisetum glaucum)-Pigeonpea (Cajanus cajan) intercropping system under rainfed conditions. Indian J Agric Sci 82(8):676-680

Blaise D, Majumdar G, Tekale K (2005) On-farm evaluation of fertilizer application and conservation tillage on productivity of cotton+ pigeonpea strip intercropping on rainfed vertisols of central India. Soil Tillage Res 84(1):108-117

Cantero-Martınez C, Angas P, Lampurlanés J (2003) Growth, yield and water productivity of barley (Hordeum vulgare L.) affected by tillage and $\mathrm{N}$ fertilization in Mediterranean semiarid, rainfed conditions of Spain. Field Crop Res 84(3):341-357 
Chai Q, Gan Y, Turner NC, Zhang RZ, Yang C, Niu Y, Siddique KHM (2014) Water-saving innovations in Chinese agriculture. Adv Agron 126(2):147-197

Cooper P, Gregory P (1987) Soil water management in the rain-fed farming systems of the Mediterranean region. Soil Use Manag 3(2):57-62

Fan XW, Li FM, Xiong YC, An LZ, Long RJ (2008) The cooperative relation between non-hydraulic root signals and osmotic adjustment under water stress improves grain formation for spring wheat varieties. Physiol Plant 132(3):283-292

Fan Z, Chai Q, Huang G, Yu A, Huang P, Yang C, Tao Z, Liu H (2013) Yield and water consumption characteristics of wheat/maize intercropping with reduced tillage in an Oasis region. Eur J Agron 45:52-58

Fang QX, Ma L, Green TR, Yu Q, Wang TD, Ahuja LR (2010) Water resources and water use efficiency in the North China plain: current status and agronomic management options. Agric Water Manag 97(8):1102-1116

FAOSTAT (2014) FAO Statistical Yearbooks - World food and agriculture. Food and Agriculture Organization of the United Nations 2013. doi:10.1073/pnas.1118568109

Fergusson L (2013) The political economy of rural property rights and the persistence of the dual economy. J Dev Econ 103(0):167-181. doi: 10.1016/j.jdeveco.2013.02.009

Gan Y, Siddique KHM, Turner NC, Li X-G, Niu J-Y, Yang C, Liu L, Chai Q (2013) Ridge-furrow mulching systems - an innovative technique for boosting crop productivity in semiarid rain-fed environments. Adv Agron 118(1):429-476. doi:10. 1007/s11104-010-0312-7

Gan Y, Liang C, Chai Q, Lemke RL, Campbell CA, Zentner RP (2014) Improving farming practices reduces the carbon footprint of spring wheat production. Nature Communications 5:5012. 10.1038/ ncomms6012

Gao Z, Yin J, Miao G, Gao F (1999) Effects of tillage and mulch methods on soil moisture in wheat fields of Loess Plateau, China. Pedosphere 9(2):161-168

Garnett T, Appleby MC, Balmford A, Bateman IJ, Benton TG, Bloomer P, Burlingame B, Dawkins M, Dolan L, Fraser D, Herrero M, Hoffmann I, Smith P, Thornton PK, Toulmin C, Vermeulen SJ, Godfray HC (2013) Agriculture. Sustainable intensification in agriculture: premises and policies. Science 341(6141):33-34. doi:10. 1126/science. 1234485

Huang G, Zhang R, Li GD, Li L, Chan K, Heenan DP, Chen W, Unkovich MJ, Robertson MJ, Cullis BR (2008) Productivity and sustainability of a spring wheat-field pea rotation in a semi-arid environment under conventional and conservation tillage systems. Field Crop Res 107(1):43-55

Kang S, Zhang J (2004) Controlled alternate partial root-zone irrigation: its physiological consequences and impact on water use efficiency. $\mathrm{J}$ Exp Bot 55(407):2437-2446
Kuo SF, Ho SS, Liu CW (2006) Estimation irrigation water requirements with derived crop coefficients for upland and paddy crops in ChiaNan Irrigation Association, Taiwan. Agric Water Manag 82(3):433-451

Li L, Sun J, Zhang F, Li X, Yang S, Rengel Z (2001) Wheat/maize or wheat/soybean strip intercropping I. Yield advantage and interspecific interactions on nutrients. Field Crop Res 71(2):123-137

Lichter K, Govaerts B, Six J, Sayre KD, Deckers J, Dendooven L (2008) Aggregation and $\mathrm{C}$ and $\mathrm{N}$ contents of soil organic matter fractions in a permanent raised-bed planting system in the Highlands of Central Mexico. Plant Soil 305(1-2):237-252

Liu Y, Wang J, Liu D, Li Z, Zhang G, Tao Y, Xie J, Pan J, Chen $F$ (2014) Straw mulching reduces the harmful effects of extreme hydrological and temperature conditions in citrus orchards. PLoS ONE 9(1)

Mu Y, Chai Q, Yu A, Yang C, Qi W, Feng F, Kong X (2013) Performance of wheat/maize intercropping is a function of belowground interspecies interactions. Crop Sci 53(5):2186-2194

Plauborg F (1995) Evaporation from bare soil in a temperate humid climate - measurement using micro-lysimeters and time domain reflectometry. Agric For Meteorol 76(1):1-17

Poumanyvong P, Kaneko S, Dhakal S (2012) Impacts of urbanization on national transport and road energy use: evidence from low, middle and high income countries. Energy Policy 46(0):268-277. doi:10. 1016/j.enpol.2012.03.059

Powlson DS, Gregory PJ, Whalley WR, Quinton JN, Hopkins DW, Whitmore AP, Hirsch PR, Goulding KWT (2011) Soil management in relation to sustainable agriculture and ecosystem services. Food Policy 36(0):S72-S87. doi:10.1016/j. foodpol.2010.11.025

Qin AZ, Huang GB, Chai Q, Yu AZ, Huang P (2013) Grain yield and soil respiratory response to intercropping systems on arid land. Field Crop Res 144:1-10

Shalizi Z (2006) Addressing China's growing water shortages and associated social and environmental consequences, vol 3895. World Bank Publications

Wang S, Zhang Y, Liu H, Yang Y, Lei R, Ma Y (2004) Study on soil moisture and benefits of the apricot-alfalfa-covering system on the slopeland of the loess regions. Science of Soil Water Conserv 2(1): 74-78

Willey R (1979) Intercropping, is importance and research needs I. Competition and yield advantage. Field Crop Abstra 32:1-20

Zhang J (2007) Barriers to water markets in the Heihe River basin in northwest China. Agric Water Manag 87(1):32-40

Zhang F, Li L (2003) Using competitive and facilitative interactions in intercropping systems enhances crop productivity and nutrient-use efficiency. Plant Soil 248(1-2):305-312 